\title{
TOWARDS INDUSTRY 4.0: A ROADMAP FOR THE SOUTH AFRICAN HEAVY INDUSTRY SECTOR
}

\author{
J. Prinsloo ${ }^{1 * \#}$, J.C. Vosloo ${ }^{1}$ \& E.H. Mathews ${ }^{1}$
}

\section{ARTICLE INFO}

\section{Article details}

Presented at the $30^{\text {th }}$ annual conference of the Southern African Institute for Industrial Engineering (SAIIE), held from 30 September - 2 October 2019 in Port Elizabeth, South Africa

Available online

15 Nov 2019

\section{Contact details}

Corresponding author

jprinsloo@researchtoolbox.com

\section{Author affiliations}

1 North-West University, CRCED-

Pretoria, Pretoria, South Africa

\# Author was enrolled for a Masters' degree at North-West University's

Centre for Research and

Continued Engineering

Development (CRCED) in Pretoria, South Africa
ABSTRACT

The rapid growth and expansion of the Internet, as well as technical advances in the area of sensor technology, allow for the interconnection of physical objects for the purpose of achieving collective goals, which paves the way for the Fourth Industrial Revolution. The Industry 4.0 paradigm is a relatively new concept that still requires detailed investigation and discussion. Standards, technologies, and overall guidelines need to be presented; thus this review paper aims to address key questions to provide some clarity on navigating the tide of Industry 4.0. The key enabling technologies, and the extent to which these technologies can be applied in industry to achieve the fundamental goals of Industry 4.0, are presented and discussed. Current challenges that hinder Industry 4.0 adoption in the South African mining sector are discussed, and a short discussion on the way forward is presented. In brief, this article aims to present a detailed roadmap for the implementation of Industry 4.0 methods in the South African mining sector. From the literature, a digital framework and toolbox have been compiled to serve as a roadmap for the way forward in successful Industry 4.0 adoption. The proposed framework and toolbox are presented, with a theoretical case study.

\section{OPSOMMING}

Die vinnige groei en uitbreiding van die internet, asook tegniese vooruitgang in sensortegnologie, het die interkonneksie van fisiese voorwerp moontlik gemaak. Dit het die weg gebaan vir die Vierde Industriële Rewolusie. Die Industrie 4.0 paradigma is 'n relatiewe nuwe konsep wat diepe ondersoek en bespreking benodig. Standaarde, tegnologieë, en algehele riglyne moet aangebied word en hierdie artikel is daarop gemik om sleutelvrae met betrekking tot Industrie 4.0 te beantwoord. Die sleutel onderliggende tegnologieë, en tot watter mate die tegnologieë toegepas kan word om die fundamentele doelstellings van Industrie 4.0 te bereik, word voorgehou en bespreek. Bestaande uitdagings wat as struikelblokke vir die aanvaarding van Industrie 4.0 in die Suid-Afrikaanse mynbedryf aangetref word, word bespreek saam met 'n kort aanbieding oor die pad vorentoe. Hierdie artikel verskaf 'n gedetailleerde padkaart vir die implementering van Industrie 4.0 metodes in die Suid-Afrikaanse mynbedryf. 'n Digitale raamwerk en gereedskapkis is vanuit die literatuur saamgestel om ten einde te dien as die padkaart. 'n Gevallestudie word ter illustrasie voorgehou.

\section{$1 \quad$ AN INTRODUCTION TO INDUSTRY 4.0}

Industrial methods and processes are in a continuous state of evolution. The roots of the manufacturing industry, as it is known today, can be traced back to the late eighteenth to early nineteenth century [1]. Since the inception of mechanical manufacturing and the use of steam power, the manufacturing and industrial realms have experienced three major revolutions. Advances 
in the underlying methods of manufacturing have not only changed the nature of industry itself, but also moulded society and directed global economic growth in a major upward trend [2], [3].

The first industrial revolution was categorised by the implementation of mechanical manufacturing procedures, with steam being the primary power driver in industry [4]. The first industrial revolution (Industry 1.0) allowed for rapid change in economic productivity and growth, with the introduction of water and steam power into society stimulating development and production [5], [6].

The advances made in the first industrial revolution were elevated to new heights in the early twentieth century with the introduction of mass labour and assembly line production. The shift to assembly line manufacturing is categorised as Industry 2.0. The implementation of conveyor-based assembly lines proved to be highly efficient, in both the time and the financial spheres, and is therefore considered to be a significant accomplishment in the manufacturing realm [7]. Electrical energy, in conjunction with mass labour production lines, played a significant role in the manufacturing industry. Reduced cost and production time, coupled with increased supply, further stimulated worldwide economic growth [8].

It can be argued that the second industrial revolution ensured the globalisation of manufacturing. Challenges such as production competitiveness, production efficiency, cost reduction, energy consumption, and production optimisation are key concerns [9]. This led to the concept of industrial automation, which is categorised as the third industrial revolution (Industry 3.0), established during the 1970s.

Industrial automation, in combination with electronic engineering and communication, aims to address social and economic challenges by increasing production uptime and efficiency while reducing production costs [10]. This ultimately improves production performance and competitiveness. Negative factors are present, however. The advent of the third industrial revolution resulted in a decline in the manual labour workforce, with many tasks being reserved for automation [11].

The term 'Industry 4.0' is an initiative spearheaded by the German government that was first brought to light during the Hanover Trade Fair in 2011. A decline of about 10 per cent in the European industrial share, and a decline in a stable workforce, led to the introduction of a revolutionary strategy to meet growth challenges [12]. To increase manufacturing output and competitiveness further, factories and production lines must be digitised, and digital collaboration must be promoted [13].

Revolutionary advances in the information and communication technology (ICT) field paved the way for this high-tech strategy. Rapid growth and expansion of the Internet, and technical advances in the area of sensor technology, allow for the interconnection of physical objects for the purpose of achieving collective goals [14]. The main strategy behind the Industry 4.0 initiative is to form an interconnected arena between various technological paradigms, such as cyber-physical systems (CPS), the Internet of Things (IoT), cloud manufacturing, knowledge integration, and information exchange [13], [15], [16].

The main objectives of the Industry 4.0 paradigm are to increase and maintain the operational efficiency of current manufacturing processes, and to advance current automation methodologies to new heights [17]. The implementation of underlying Industry 4.0 methods and principles will result in the establishment and incorporation of smart factories, smart products, and smart services in society as a whole [18]. Figure 1 illustrates an architectural summary of the evolution of manufacturing, starting from the first industrial revolution and ending in the current state of Industry 4.0 .

The Industry 4.0 paradigm is a relatively new concept that still requires detailed investigation and discussion. This is especially important if global industrial adoption is to take place. Standards, technologies, and overall guidelines need to be presented; this review paper thus aims to address the following key questions to provide some clarity on navigating the tide of Industry 4.0:

- What is the underlying architecture of Industry 4.0?

- What are the key enabling technologies of Industry 4.0, and to what extent can these technologies be applied to achieve the defined goals of Industry 4.0 ? 
- What are the current challenges that might hinder Industry 4.0 adoption in the South African mining industry?

- What will be the way forward?

In brief, this article aims to present a detailed roadmap for the implementation of Industry 4.0 methods in the South African mining sector. A digital framework and toolbox are presented to address current gaps in this sector.

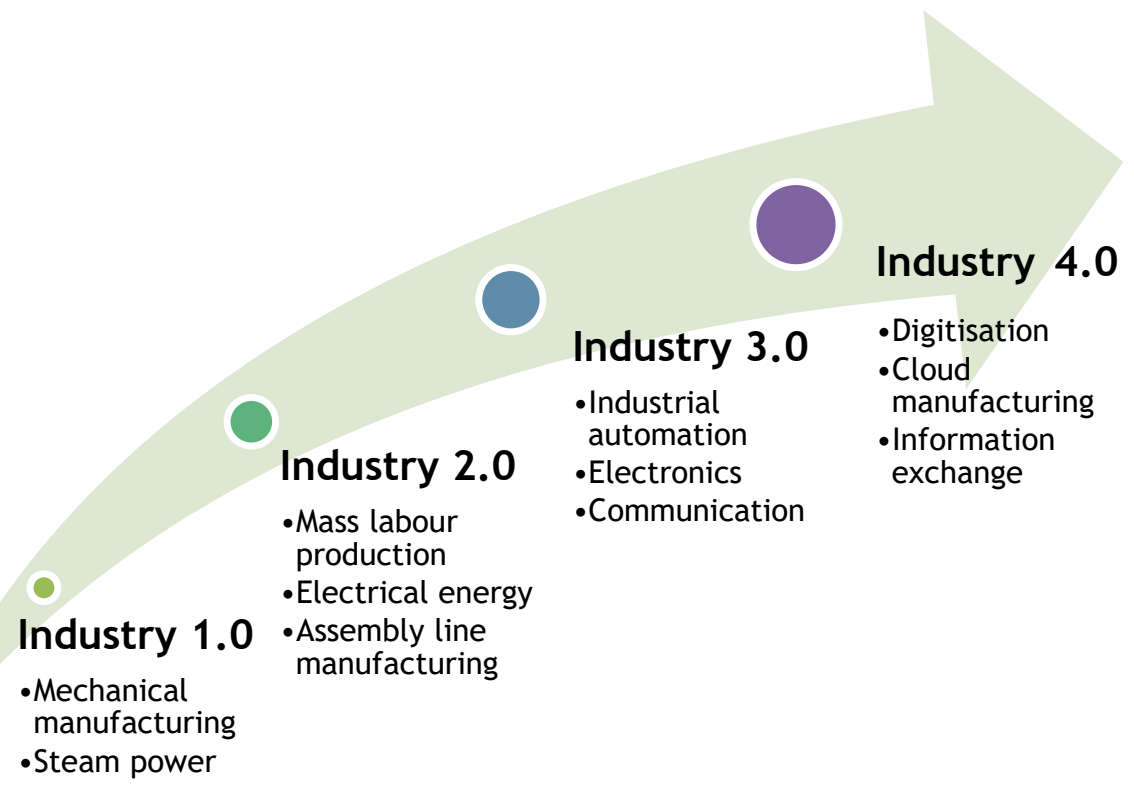

Figure 1: The history of industrial advancement

\section{THE INDUSTRY 4.0 REALM: AN ARCHITECTURAL STUDY}

With Industry 4.0 being a relatively new paradigm, no clear architectural description can be presented from the literature. This section aims to provide an architectural study to illustrate the value of adopting Industry 4.0 principles in practice. An input-output methodological approach was followed to deconstruct the Industry 4.0 concept into two parts.

The first part serves as the input model for Industry 4.0, and is labelled the 'Industry 4.0 digital framework'. The main objective of the digital framework is to introduce various concepts, models, and technologies that are underlying components that are required for Industry 4.0. The second part serves as the output model for Industry 4.0, and is labelled the 'Industry 4.0 digital toolbox'. The objective of the digital toolbox is to present various enabling tools and methodologies that can be used to embed the Industry 4.0 vision in the industrial and manufacturing sector.

The concepts, models, and technologies present in the digital framework serve as key enablers for the implementation of tools and methodologies present in the digital toolbox. The scope and reach of the digital toolbox will be limited if several digital framework components are removed. Figure 2 illustrates a top-down approach to deconstructing the Industry 4.0 paradigm. Several applications and examples of the digital framework and digital toolbox are presented in the final level of the Sankey diagram to emphasise the scope of the proposed framework and toolbox.

Both the framework and the digital toolbox are developed in the sections that follow. The value drivers and technological levers that form part of the Industry 4.0 digital toolbox have also been presented in previous work [13], [19], [20]. 


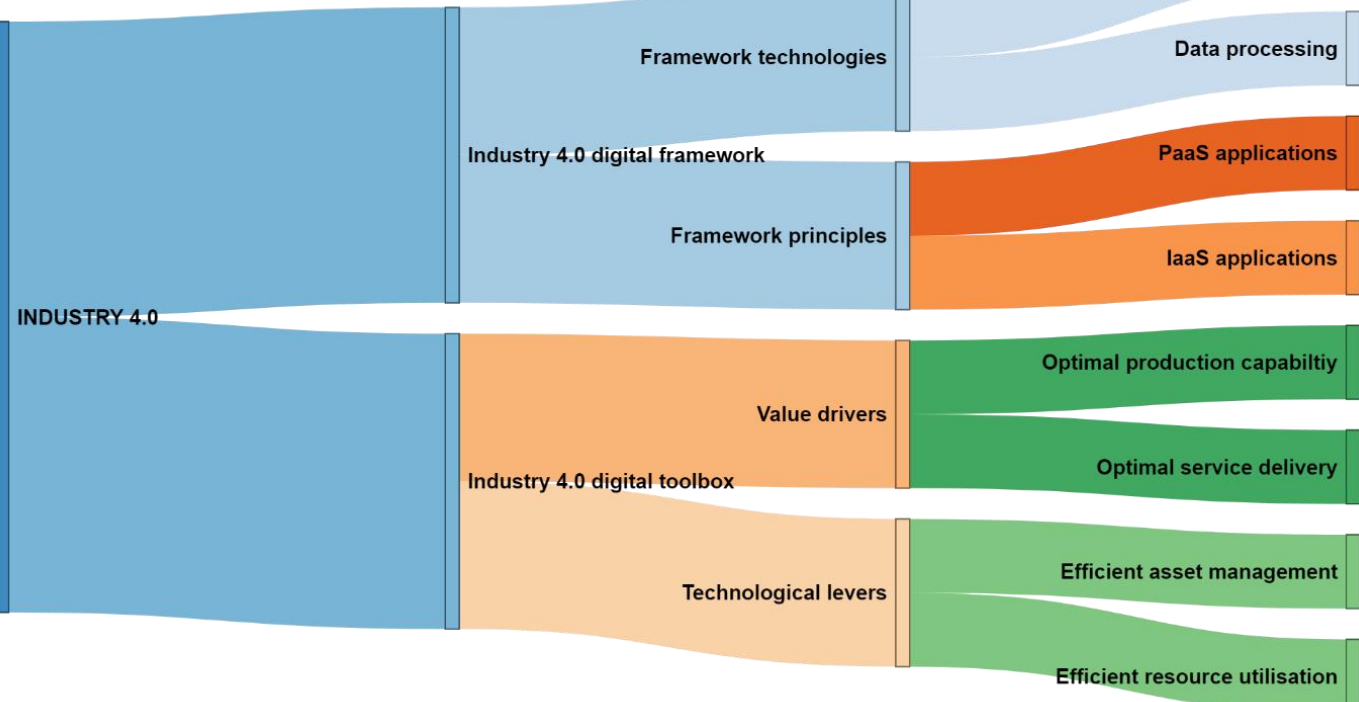

Figure 2: A deconstructed architectural view of the Industry 4.0 paradigm (see online version for colour)

\subsection{The Industry 4.0 digital framework}

For Industry 4.0 to be adopted into the industrial sector, various standards, methodologies, and technologies must first be introduced and incorporated into society. These all form part of a digital framework that will allow a digital toolbox to be created. The Industry 4.0 digital framework contains two main underlying components, which can be labelled as 'framework technologies' and 'framework principles'. Five key framework technologies have been identified from the literature [17], [21]-[23]. These technologies are viewed as core-enabling technologies, and are discussed in detail in Section 3 of this paper. Cyber-physical systems, the Internet of Things, big data, decentralised computing, and wireless networks form the technological backbone of the Industry 4.0 digital framework. Various published applications of these framework technologies are reported in Table 1.

Table 1: Literature survey overview of Industry 4.0 technologies and principles

\begin{tabular}{|l|l|l|l|}
\hline \multicolumn{4}{|c|}{ Industry 4.0 digital framework } \\
\hline Framework technologies & Publications & Framework principles & Publications \\
\hline Cyber-physical systems & {$[24]$} & Decentralisation & {$[25]$} \\
\hline Internet of Things (IoT) & {$[26]-[28]$} & Real-time capability & {$[29]$} \\
\hline Big data & {$[30],[31]$} & Modularity & {$[32]$} \\
\hline Decentralised computing & {$[17],[23],[33]$} & Interoperability & {$[34]$} \\
\hline Wireless networks & {$[35]-[37]$} & Virtualisation & {$[38]$} \\
\hline
\end{tabular}

Cyber-physical systems can be defined as industrial automation systems that are interconnected through communication networks. This interconnection enables the performance of collective operations and the exchange of information between the physical devices and the software infrastructure [24]. Cyber-physical systems enable real-time information exchange, which can improve overall manufacturing performance. Benefits such as increased productivity, optimised energy consumption, and efficient use of production-related resources can be realised [39]. Without the implementation of cyber-physical systems, a real-time information exchange will be difficult to achieve; and this can effectively nullify the benefits underlying Industry 4.0 adoption.

The concept known as the Internet of Things is relatively new, but has already proven to be a major component in shaping the information and communication technology field. By expanding the Internet into the physical realm, individual hardware devices can be transformed into intelligent 
systems operating on a collective level [40]. A lack of intelligence and collective collaboration would hamper the ability to make informed decisions, acting as a stumbling block for Industry 4.0 adoption. The rapid expansion in the implementation of cyber-physical systems and loT applications results in massive amounts of raw data. This data must be stored and processed in a real-time fashion. The rapid expansion in raw data sets has led to the establishment of a technology known as 'big data' [41]. Large amounts of raw data prove to be challenging to process and maintain if traditional dataset methodologies are used [42]. Big data presents several methodologies that prove to be efficient for processing and storing large dataset volumes. The benefits of big data systems are increased data processing speed and efficient data storage. This, in turn, aids cyber-physical system scalability [42]. Industry 4.0 ecosystems rely on continuous information exchange; therefore, the absence of big data infrastructure and methodologies reduces the robustness and effectiveness of information exchange processes.

The realisation of cyber-physical systems, and the incorporation of these systems into existing industrial processes, inevitably leads to the generation of massive amounts of raw data. Decentralised computing encompasses technologies and fields such as artificial intelligence (Al), data analysis, and decentralised data storage. Decentralised big data storage schemes facilitate decentralised data storage; but to convey meaning from raw data, intelligent algorithms and data analysis methodologies must be developed [30].

The incorporation of decentralised computing power into the physical realm realises benefits such as self-sufficiency, self-optimisation, and autonomous decision-making. Intelligent systems can learn from the massive amounts of raw data. Decisions made by intelligent systems can be provided as inputs to cyber-physical systems [41]. This provides a feedback loop in which continuous production improvement can be sustained through continuous training. The result: a fully integrated and coordinated Industry 4.0 ecosystem that can respond and adapt to real-time changes in production [43]. The absence of decentralised computing would have a negative impact on the responsiveness and quality of service (QoS) of an Industry 4.0 ecosystem.

Wireless communication can be considered the backbone of an Industry 4.0 ecosystem [44]. It allows for real-time information flow between cyber-physical systems and decentralised storage and computing mechanisms. The absence of wireless communication methods would impair the ability of physical devices to adapt to real-time changes, and this would lead to disruptions in service. In contrast, a highly stable wireless network infrastructure results in stable communication and information exchange between cyber-physical devices and existing cloud computing services. An uninterrupted exchange of data and information results in an overall improvement in the QoS of an Industry 4.0 ecosystem [45].

While the technologies and methods discussed above are key enablers of Industry 4.0, several principles also exist to serve as classifiers. The five framework principles listed in Table 1 , and established from the literature, aim to define how an Industry 4.0 ecosystem is presented [17], [22], [39], [46], [47]. These five principles must be present, and the underlying technologies must support these principles. Two of the five principles, real-time capability and decentralisation, aim to support the remaining three principles, modularity, interoperability, and virtualisation.

The two key principles that allow for real-time adoption and self-configuration are the principles of decentralisation and real-time capability. Cloud-based intelligent systems, separated from physical devices, allow for real-time decentralised decision-making to adapt to changing demands [48]. This creates flexibility and allows for the creation of smart industries that can perceive, learn, and adapt. Decentralisation allows for modularity to be incorporated into industry designs. By re-allocating various resources off-site, modular production systems that receive input from cloud-based intelligent systems can be facilitated. The key enabling technologies discussed above allow for the interconnection of various modular systems, which promotes interoperability between these systems. Remote intelligence, as well as interconnected modular systems, allows for virtualisation to take place, in which a physical copy of industrial systems is transferred to the virtual domain [29].

The principles discussed above are the key enablers spearheading digitisation, cloud manufacturing, and real-time information exchange, as illustrated by Figure 1. The adoption of Industry 4.0 practices can greatly benefit industrial systems, especially the heavy industry realm, which has been reluctant to adopt Industry 4.0 methods, technologies, and principles [49]. The Industry 4.0 digital 
framework is the gateway to the incorporation and application of various technological levers in industry. Section 2.2 discusses how the Industry 4.0 digital toolbox can function with the Industry 4.0 digital framework in place.

\subsection{The Industry 4.0 digital toolbox}

The digital framework presented in the previous section allows for the creation of an Industry 4.0 digital toolbox. It should be noted that the Industry 4.0 digital framework discussed in the previous section facilitates the use of the proposed Industry 4.0 digital toolbox. Industry 4.0 can be incorporated into the industrial society by implementing technological levers and methodologies enabled by the digital toolbox. This will have a direct effect on existing value drivers in industry. Figure 3 gives a graphical representation of the overall Industry 4.0 architecture, divided into the Industry 4.0 framework and the Industry 4.0 toolbox.

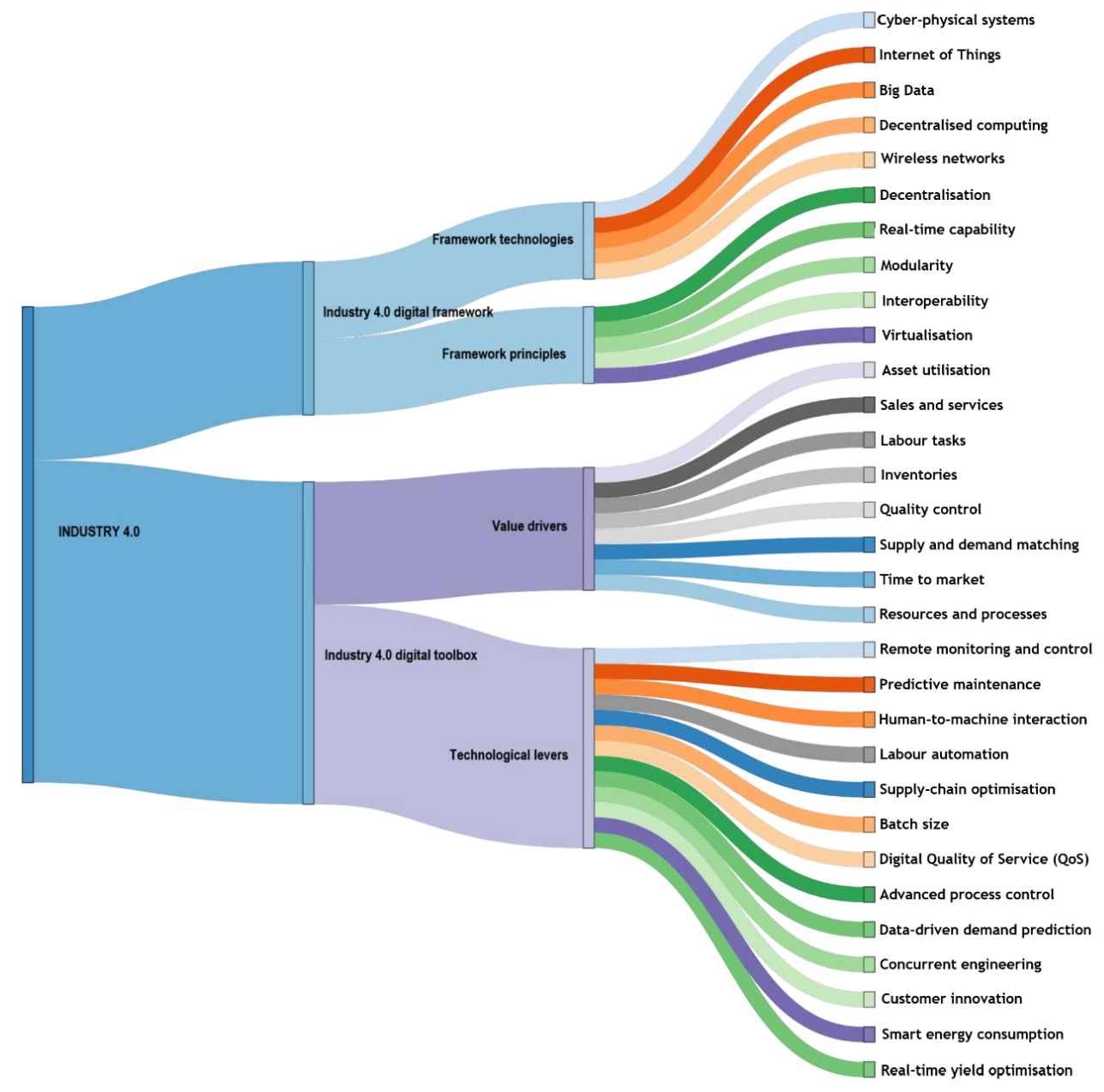

Figure 3: A detailed architectural overview of Industry 4.0 (see online version for colour)

The Industry 4.0 digital toolbox contains two main underlying components, Industry 4.0 value drivers and Industry 4.0 technological levers. Table 2 summarises the digital toolbox, and presents related publications where these technological levers are used in industry.

Several technological levers assist with labour tasks in the industrial sector. These include humanto-machine interaction, remote monitoring and control procedures, performance management structures, and labour automation. Human-to-machine interaction plays a critical role in an Industry 4.0 setup. It is believed that the primary role of human labour will be to dictate a specific production strategy and oversee the execution of that strategy [46]. Numerous challenges will be present in a fully functional Industry 4.0 environment, which implies that a human labour presence is still required to stimulate creative problem-solving in the workplace [46]. The Industry 4.0 digital 
framework allows for most repetitive labour tasks to be automated across the industrial production line.

Table 2: Literature survey overview of Industry 4.0 value drivers and technological levers (adapted from [19])

\begin{tabular}{|c|c|c|}
\hline \multicolumn{3}{|c|}{ Industry 4.0 digital toolbox } \\
\hline Value drivers & Technological levers & Publications \\
\hline \multirow{2}{*}{ Asset utilisation } & Remote monitoring and control & \multirow{2}{*}[50]{,$[51]$} \\
\hline & Predictive maintenance & \\
\hline \multirow{2}{*}{ Labour tasks } & Human-to-machine interaction & \multirow{2}{*}[52]{} \\
\hline & Labour automation & \\
\hline \multirow{2}{*}{ Inventories } & Supply-chain optimisation & \multirow{2}{*}{ [8] } \\
\hline & Batch size & \\
\hline \multirow{2}{*}{ Quality control } & Digital Quality of Service (QoS) & \multirow{2}{*}{ [7] } \\
\hline & Advanced process control & \\
\hline Supply and demand matching & Data-driven demand prediction & [53] \\
\hline \multirow{2}{*}{ Time-to-market } & Concurrent engineering & \multirow{2}{*}{ [43] } \\
\hline & Customer innovation & \\
\hline \multirow{2}{*}{ Sales and service } & Predictive maintenance & \multirow{2}{*}{ [50], [51] } \\
\hline & Remote monitoring and control & \\
\hline \multirow{2}{*}{ Resources and processes } & Smart energy consumption & \multirow{2}{*}{ [54] } \\
\hline & Real-time yield optimisation & \\
\hline
\end{tabular}

\section{INDUSTRY 4.0 ADOPTION IN THE SOUTH AFRICAN MINING SECTOR}

With the clear architectural overview presented in the previous section, this section aims to use the overview to illustrate the Industry 4.0 adoption gap currently present in the South African mining sector. Current challenges in mining operations are first presented. Various existing systems are then presented from the literature that contributes to Industry 4.0 adoption practices. These existing solutions are then used to simplify Figure 3 accurately to illustrate the Industry 4.0 gap in the context of the South African mining sector. This section concludes with a short summary of the findings.

\subsection{The current Industry 4.0 scope in the mining sector}

The South African mining industry is involved in a continuous battle to remain profitable [55]. Factors such as government regulation and market-related pressures force the industry to investigate other methods of achieving sustainable mining operations [53]. Reducing capital expenditure has been identified as the primary method of remaining profitable. Key focus points that have a direct impact on sustainable mining operations include asset management strategies, monitoring and maintenance strategies, and energy usage profiles [52], [54], [56]. These focus points are key areas for potential Industry 4.0 solutions.

The geographical layout of deep-level mines makes it difficult to implement loT-based solutions. A mining operation usually consists of several operational systems. These systems are divided between surface operations and underground operations [57]. Current Industry 4.0 practices emphasise wireless communication [33]. This is a major concern, since mining systems are often separated by large geographical distances, both horizontally and vertically [55]. This geographical separation limits the operation of wireless communication networks. Wireless communication infrastructure in harsh underground conditions is required to remain stable. Instability in the wireless communication infrastructure will effectively nullify the advantages Industry 4.0 has to offer. In addition to geographical constraints, limited access to existing equipment and ageing infrastructure further hamper the adoption of Industry 4.0 practices.

The challenges mentioned above limit the ability of a mine to respond and adapt to the current Industry 4.0 tide. Various loT-related initiatives have, however, been implemented in the mining sector to assist with the key focus points discussed above. Most of these initiatives focus on the implementation of condition-based maintenance systems and remote monitoring and maintenance systems [50], [52], [58], [59]. Energy management information systems (EMIS) and automatic electricity bill analysis initiatives have also been implemented to assist heavy industry players with efficient operations [53], [54]. 
Condition-based maintenance systems and remote monitoring and maintenance systems form part of the technological levers present in the Industry 4.0 digital toolbox. In the context of mining operations, these systems use existing supervisory control and data acquisition (SCADA) systems to execute data collection routines. The collected data is then transmitted off-site, stored, and analysed in a central database system. The use of SCADA systems for data collection is an appropriate method, given the present infrastructural challenges in mining operations; however, the quality and extensibility of SCADA networks can hamper the quality of data collection routines [60].

Prinsloo, Mathews, du Plessis, and Vosloo [61] developed a software-based monitoring and information system to ensure wireless communication stability for effective data transmission. The analysis of the transmitted data allows various asset management strategies to be implemented. Goosen, Mathews, and Vosloo [54] proposed an electricity bill analysis system that makes use of an existing EMIS for data processing. In the scope of condition-based maintenance strategies, Van Jaarsveld, van Heerden, and van Rensburg [52] proposed an automated condition-based information system to assist with existing condition-based maintenance strategies. The main challenge present in condition monitoring systems is the analysis of large amounts of data for decision-making purposes. Van Jaarsveld et al. [52] simplified this process by providing a refined and simplified method to analyse the operational condition of a mining system's equipment.

\subsection{Industry 4.0 adoption potential}

To evaluate the potential for Industry 4.0 adoption in the South African mining industry, the availability of the framework elements required to make Industry 4.0 adoption feasible must first be investigated. After all framework elements have been identified, the various toolbox elements that are enabled through the available framework components can be identified. This will emphasise any limitations and gaps present, and will produce an Industry 4.0 adoption roadmap that can be followed.

The South African mining environment still uses the traditional industry model of centralisation [58]. Equipment is monitored and controlled from a central point, usually an industrial SCADA system, and all information is distributed via a wired telemetry system to various industrial endpoints. To allow Industry 4.0 practices to be adopted in the mining sector, a push for decentralisation and wireless interconnection must be made. The facilitation of interconnected modular systems, which allow virtualisation to take place, will effectively allow for a virtual copy of mining operations to be made. This virtual copy, referred to as a digital twin, can be considered the next step in managing mining operations. Wired telemetry still allows real-time capabilities, such as rapid responses to service delivery and production, but these capabilities are limited to local mining operations. For expert condition-based maintenance strategies to be implemented, big data and decentralised computing must be incorporated into the current operational infrastructure context.

Mining operations can be improved and optimised by incorporating intelligent systems, sensors, and other IoT-related technologies into the existing infrastructure. The next step would be to incorporate predictive maintenance strategies into existing EMIS infrastructures, to increase operational efficiency methodologies further. The expansion and incorporation of wireless sensor networks into the heavy industry realm has already been proposed, and solutions that actively focus on the improvement of mining operations and safety have been presented [62]-[64]. Figure 4 gives an overview of the key Industry 4.0 components that should be investigated and possibly incorporated into the mining sector. Key principles, drivers, and levers that have not been integrated into South African mining operations are marked in grey, while existing functionality is marked in black.

Figure 4 clearly shows that there is great potential for the adoption of Industry 4.0 practices in the mining sector. The value that Industry 4.0 adds to the mining sector is illustrated by the Industry 4.0 digital toolbox. It is, however, impossible to implement the digital toolbox fully if the digital framework does not exist. Key framework technologies and principles must, therefore, be incorporated before the digital toolbox can be applied, starting with the five framework technologies: cyber-physical systems, loT, big data, decentralised computing, and wireless networks. 


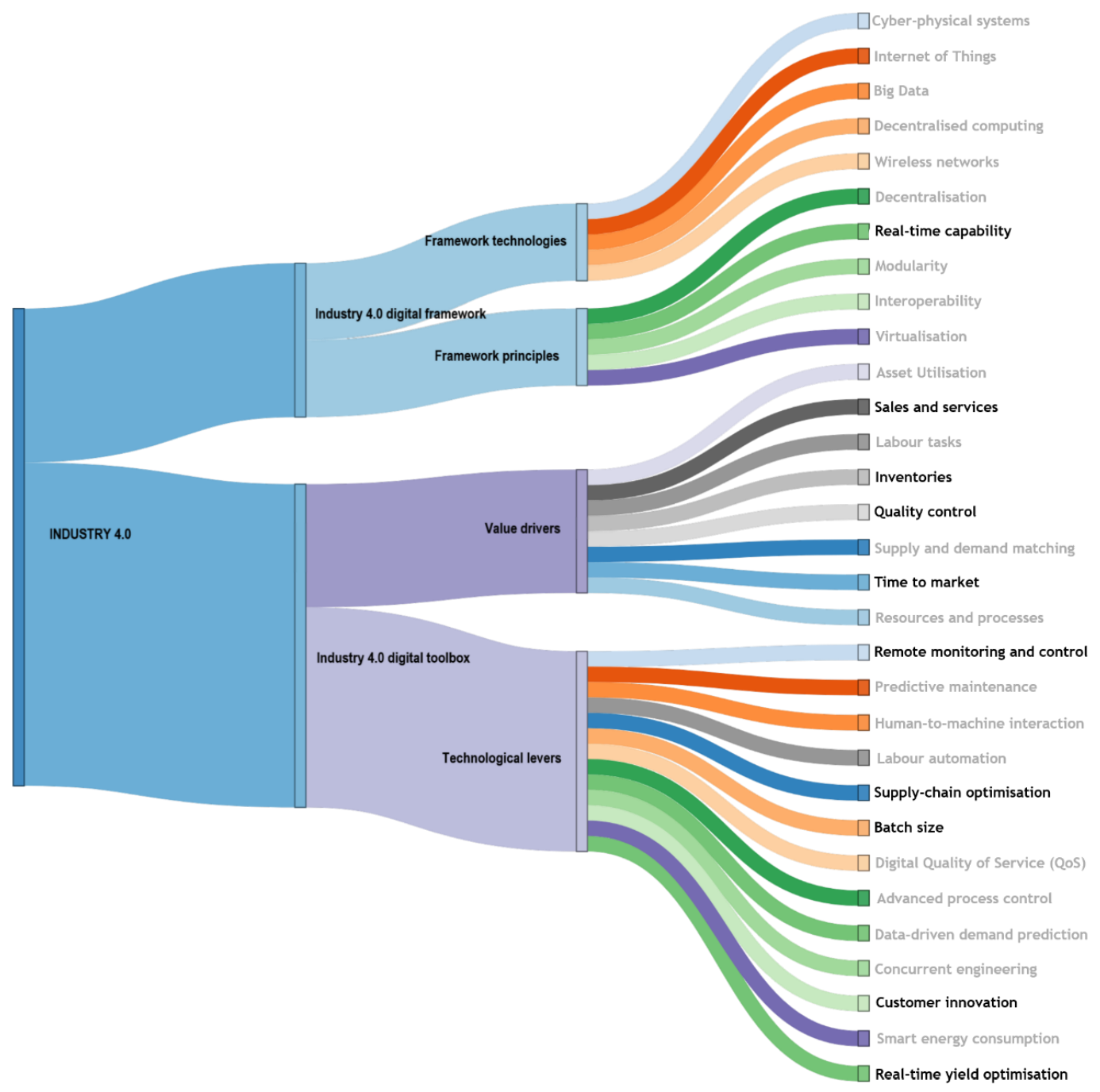

Figure 4: Key Industry 4.0 focus points for the South African mining sector (see online version for colour)

\section{KEY CHALLENGES IN THE INDUSTRY 4.0 REALM}

Challenges exist that can hamper the effective adoption of Industry 4.0 methods and practices in the heavy industry sector. This section presents several challenges that must be addressed, divided into two main sections. The first section presents physical challenges that directly affect the core principles of Industry 4.0. The second section presents several psychological challenges that have an indirect effect on the adoption of Industry 4.0 methods. These challenges are summarised in Table 3.

Table 3: A summary of current Industry 4.0 challenges

\begin{tabular}{|l|l|l|l|}
\hline \multicolumn{5}{|c|}{ Industry 4.0: Summary of challenges } \\
\hline Physical challenges & Publications & Psychological challenges & Publications \\
\hline Interoperability & {$[65]$} & Impact on labour & {$[66]$} \\
\hline Accessibility & {$[45],[67]$} & Technical skill-sets and education & {$[66]$} \\
\hline Security and privacy & {$[33],[68]$} & Financial perspectives & {$[16]$} \\
\hline
\end{tabular}

\subsection{Physical challenges}

The decentralised nature of Industry 4.0 requires the integration of various end-point devices. These devices range from actuators and sensors to data relay nodes [47]. To ensure stable and reliable 
communication between devices, communication protocols and standards need to be developed and enforced in industry [65]. The implementation of these standards can be cumbersome. To assist with this, several standardisation bodies exist that focus on drafting, establishing, and enforcing standards. These bodies include the Internet Engineering Task Force (IETF), the Institute for Electrical and Electronics Engineers (IEEE), and the European Telecommunications Standards Institute (ETSI) [65].

The communication framework and network layer of Industry 4.0-enabled systems is critical for effective operation. Wireless sensor networks, machine-to-machine communication, and wide-area wireless communications form the backbone of the Industry 4.0 network layer, and ensure interoperability between subsystems and nodes. Elghazel et al. [45] state that these technologies are prone to failure and can render an Industry 4.0-enabled system useless. Due to the remoteness of industrial facilities, wide-area wireless communications are employed to achieve real-time data transfer and information exchange. External interference and changes in network topology can hamper the quality of wide-area wireless communications [67]. To address these challenges in network instability, software-based information systems are required to monitor the quality and status of wide-area wireless communications. This will ensure operational stability of the network layer for industrial operations using Industry 4.0 applications.

Security and privacy are crucial factors that can hamper any digital system. Cybersecurity must be considered a top priority to protect critical industrial systems and ensure operational uptime. With the introduction of various communication standards and protocols, it is required to establish secure network policies and authentication procedures [33]. Ensuring adequate information security and privacy in a decentralised environment, such as a smart factory, can be a difficult task [68]. Xu, He, and $\mathrm{Li}[68]$ argue that information security and the protection of critical systems are more difficult to maintain due to an increase in the number of attack vectors that are present in an Industry 4.0 ecosystem. Aspects such as point-to-point data encryption and cloud-based security applications must be explored to enforce security and privacy effectively in the Industry 4.0 domain.

\subsection{Psychological challenges}

Research and development of new technologies has a direct impact on the ability, skills, and education of people [66]. With rapid advances being made in all areas of technology, traditional education principles will be required to adapt. This will ensure that the necessary skill-sets will be available to implement and maintain specialised equipment and technologies. Benešová and Tupa [66] state that communication and collaboration between industries and academic institutions must be established to ensure that academic, research, and industry applications remain aligned. This will ensure that a skilled workforce is available to implement and maintain Industry 4.0 methods and applications.

To enable the research and development of new technologies, financial support is needed. A general challenge for frontier-type technologies is the reluctance to support the development and improvement of these technologies financially. Investors generally prefer 'tried and tested' methods above the 'new but unproven' approach. Significant investment in the development of Industry 4.0 applications is required to ensure global adoption [16].

\section{INDUSTRY 4.0: THE WAY FORWARD}

Although Industry 4.0 is a European initiative, the effects of this paradigm shift can already be witnessed in industrial sectors around the globe [18], [69], [70]. Incorporating Industry 4.0 methods and technologies will have a profound effect on national industrial and economic growth [38]. Industry 4.0 is, however, not without its challenges. Initiatives such as 'Made in China 2025', an industrial development plan spearheaded by China and published in 2015, and the gradual reindustrialisation of the manufacturing and industrial sectors of the United States, are considered to be competitors to the European Industry 4.0 vision [47]. All initiatives, however, strive toward a unified goal of digital transformation and enhancement that will ultimately lead to the Fourth Industrial Revolution.

Zhong, Xu, Klots, and Newman [34] highlight several key aspects in the field of intelligent manufacturing that should be considered as the next phase of industrial development. These aspects include the creation and provision of intelligent manufacturing models, the extension of humanmachine collaboration, and the application of data-driven manufacturing models. These aspects 
open the gate to a new arena of smart design, smart monitoring procedures, smart control, and smart job scheduling. Vaidya, Ambad, and Bhosle [16] state that advancement in the areas of organised supply chain management and optimised maintenance and production scheduling will continue to develop, and that a symbiotic relationship between human and machine interactions will develop.

\section{CONCLUSION}

This paper has presented a detailed architectural study of the Industry 4.0 paradigm. The digital framework and the digital toolbox proposed in this paper clearly highlight key areas of importance that must be addressed before Industry 4.0 adoption can take place. To illustrate the utility of the proposed architectural model, a theoretical case study was developed. In the context of the South African mining industry, a methodological shift must be made from traditional centralised operations to decentralised computing. This, together with the implementation of wireless sensor network infrastructure, will assist in the development and advancement of asset management systems, condition-based maintenance systems, and energy management systems. The incorporation of sensors and decentralised computing will enable the incorporation of predictive maintenance strategies, which in turn will improve the operational uptime of equipment.

The South African mining industry serves as an example of how the proposed framework was applied to identify Industry 4.0 adoption hurdles. The way forward is to use this framework to identify potential gaps that might hinder Industry 4.0 adoption in the heavy industry sector. After the framework has been laid down, the next step is to develop and implement the necessary tools and processes that will ensure successful Industry 4.0 adoption in the heavy industry sector.

The successful adoption of Industry 4.0 practices on a national scale - for example, in the Republic of South Africa - requires changes in current social and economic structures. For Industry 4.0 initiatives to be successful, social and economic systems must be created with the ability to respond dynamically to local and global changes. The required infrastructure to sustain Industry 4.0 methods and frameworks must be developed and integrated into society on a national scale. Finally, Industry 4.0 awareness must be created to foster a mindset of technological advancement on a social, economic, and industrial level.

\section{REFERENCES}

[1] Lukac, D. 2016. The fourth ICT-based industrial revolution 'Industry 4.0': HMI and the case of CAE/CAD innovation with EPLAN P8. 23rd Telecommunications Forum, pp. 835-838.

[2] Trew, A. 2014. Spatial takeoff in the first industrial revolution. Review of Economic Dynamics, 17(4), pp. 707-725.

[3] Clark, G. 2014. The industrial revolution. 2. Amsterdam: Elsevier B.V.

[4] Bruland, K. \& Smith, K. 2013. Assessing the role of steam power in the first industrial revolution: The early work of Nick von Tunzelmann. Research Policy, 42(10), pp. 1716-1723.

[5] Von Tunzelmann, N. 2003. Historical coevolution of governance and technology in the industrial revolutions. Structural Change and Economic Dynamics, 14(4), pp. 365-384.

[6] Barca, S. 2011. Energy, property, and the industrial revolution narrative. Ecological Economics, 70(7), pp. 1309-1315.

[7] Liu, C., Li, W., Lian, J. \& Yin, Y. 2012. Reconfiguration of assembly systems: From conveyor assembly line to serus. Journal of Manufacturing Systems, 31(3), pp. 312-325.

[8] Joseph, O.A. \& Sridharan, R. 2011. Analysis of dynamic due-date assignment models in a flexible manufacturing system. Journal of Manufacturing Systems, 30(1), pp. 28-40.

[9] Sun, B., Jämsä-Jounela, S.L., Todorov, Y., Olivier, L.E. \& Craig, I.K. 2017. Perspective for equipment automation in process industries. IFAC-PapersOnline, 50(2), pp. 65-70.

[10] Dirican, C. 2015. The impacts of robotics, artificial intelligence on business and economics. World Conference on Technology, Innovation and Entrepreneurship, 195, pp. 564-573.

[11] Eden, M. \& Gaggl, P. 2018. On the welfare implications of automation. Review of Economic Dynamics, 29, pp. 15-43.

[12] Hofmann, E. \& Rüsch, M. 2017. Industry 4.0 and the current status as well as future prospects on logistics. Computers in Industry, 89, pp. 23-34.

[13] Sung, T.K. 2017. Industry 4.0: A Korea perspective. Technological Forecasting and Social Change, 132(2018), pp. 40-45.

[14] Isaka, H., Nagayoshi, H., Yoshikawa, H., Yamada, T. \& Kakeno, N. 2016. Next generation of global production management using sensing and analysis technology. Hitachi Review, 65(5), pp. 47-52.

[15] Zezulka, F., Marcon, P., Vesely, I. \& Sajdl, O. 2016. Industry 4.0: An introduction in the phenomenon. IFAC-PapersOnline, 49(25), pp. 8-12. 
[16] Vaidya, S., Ambad, P. \& Bhosle, S. 2018. Industry 4.0: A glimpse. 2nd International Conference on Materials Manufacturing and Design Engineering, 20, pp. 233-238.

[17] Thames, L. \& Schaefer, D. 2016. Software-defined cloud manufacturing for Industry 4.0. Changeable, Agile, Reconfigurable \& Virtual Production, 52, pp. 12-17.

[18] Stock, T. \& Seliger, G. 2016. Opportunities of sustainable manufacturing in Industry 4.0. 13th Global Conference on Sustainable Manufacturing, 40, pp. 536-541.

[19] Baur, C. \& Wee, D. 2015. Manufacturing's next act. [Online]. Available: https: / / www.mckinsey.com/business-functions/operations/our-insights/manufacturings-next-act [Accessed: 18-Apr-2018].

[20] Sackey, S.M. \& Bester, A. 2016. Industrial engineering curriculum in Industry 4.0 in a South African context. South African Journal of Industrial Engineering, 27(4), pp. 101-114.

[21] Rana, A. \& Lehal, G.S. 2015. Smart computing prototype for Industry 4.0 revolution with IOT and bigdata implementation model. Indian Journal of Science and Technology, 8, pp. 1-7.

[22] Gruber, F.E. 2013. Industry 4.0: A best practice project of the automotive industry. Digital Product and Process Development Systems, 411, pp. 36-40.

[23] Mařík, V., Schirrmann, A., Trentesaux, D. \& Vrba, P. 2015. Big data semantics in Industry 4.0. 7th International Conference on Industrial Applications of Holonic and Multi-Agent Systems, 9266, pp. 217229.

[24] Bagheri, B., Yang, S., Kao, H.A. \& Lee, J. 2015. Cyber-physical systems architecture for self-aware machines in Industry 4.0 environment. IFAC-PapersOnline, 28(3), pp. 1622-1627.

[25] Qin, J., Liu, Y. \& Grosvenor, R. 2016. A categorical framework of manufacturing for Industry 4.0 and beyond. Changeable, Agile, Reconfigurable \& Virtual Production, 52, pp. 173-178.

[26] Al-Taee, M.A., Khader, O.B. \& Al-Saber, N.A. 2007. Remote monitoring of vehicle diagnostics and location using a smart box with global positioning system and general packet radio service. IEEE/ACS International Conference on Computer Systems and Applications, pp. 385-388.

[27] Prinsloo, J. \& Malekian, R. 2016. Accurate vehicle location system using RFID, an Internet of Things approach. Sensors, 16(6), p. 825.

[28] Satija, U., Ramkumar, B. \& Manikandan, M.S. 2017. Real-time signal quality-aware ECG telemetry system for loT-based health care monitoring. IEEE Internet of Things Journal, 4(3), pp. 815-823.

[29] Qi, Q. \& Tao, F. 2018. Digital twin and big data towards smart manufacturing and Industry 4.0: 360 degree comparison. IEEE Access, 6, pp. 3585-3593.

[30] Ghofrani, F., He, Q., Goverde, R.M.P. \& Liu, X. 2018. Recent applications of big data analytics in railway transportation systems: A survey. Transportation Research Part C: Emerging Technologies, 90, pp. 226246.

[31] Rana, A. \& Lehal, G.S. 2015. Smart computing prototype for Industry 4.0 revolution with IOT and bigdata implementation model. Indian Journal of Science and Technology, 8(35), pp. 1-7.

[32] Sackey, S.M., Bester, A. \& Adams, D. 2017. Industry 4.0 learning factory didactic design parameters for industrial engineering education in South Africa. South African Journal of Industrial Engineering, 28(1), pp. 114-124.

[33] Wan, J., Tang. S., Shu, Z., Li, D., Wang, S., Imran, M., \& Vasilakos, A. 2016. Software-defined industrial Internet of Things in the context of Industry 4.0. IEEE Sensors Journal, 16(20), pp. 7373-7380.

[34] Zhong, R.Y., Xu, X., Klotz, E. \& Newman, S.T. 2017. Intelligent manufacturing in the context of Industry 4.0: A review. Engineering, 3, pp. 616-630.

[35] Rashid, B. \& Rehmani, M.H. 2016. Applications of wireless sensor networks for urban areas: A survey. Journal of Network and Computer Applications, 60, pp. 192-219.

[36] Muduli, L., Mishra, D.P. \& Jana, P.K. 2018. Application of wireless sensor network for environmental monitoring in underground coal mines: A systematic review. Journal of Network and Computer Applications, 106, pp. 48-67.

[37] Prathiba, B., Jaya Sankar, K. \& Sumalatha, V. 2016. Enhancing the data quality in wireless sensor networks: A review. International Conference on Automatic Control and Dynamic Optimization Techniques (ICACDOT), pp. 448-454.

[38] Keller, M., Rosenberg, M., Brettel, M. \& Friederichsen, N. 2014. How virtualization, decentralization and network building change the manufacturing landscape: An Industry 4.0 perspective. International Journal of Mechanical, Aerospace, Industrial, Mechatronic and Manufacturing Engineering, 8(1), pp. 37-44.

[39] Ivanov, D., Sokolov, B. \& Ivanova, M. 2016. Schedule coordination in cyber-physical supply networks Industry 4.0. IFAC-PapersOnline, 49(12), pp. 839-844.

[40] Miorandi, D., Sicari, S., De Pellegrini, F. \& Chlamtac, I. 2012. Internet of Things: Vision, applications and research challenges. Ad Hoc Networks, 10(7), pp. 1497-1516.

[41] Zhang, Q., Yang, L.T., Chen, Z. \& Li, P. 2018. A survey on deep learning for big data. Information Fusion, 42, pp. 146-157.

[42] Boubiche, S., Boubiche, D.E. \& Toral-Cruz, H. 2018. Big data challenges and data aggregation strategies in wireless sensor networks. IEEE Access, 6, pp. 20558-20571.

[43] Lee, J., Kao, H.A. \& Yang, S. 2014. Service innovation and smart analytics for Industry 4.0 and big data environment. 6th CIRP Conference on Industrial Product-Service Systems, 16, pp. 3-8.

[44] Dhillon, H.S., Huang, H. \& Viswanathan, H. 2017. Wide-area wireless communication challenges for the Internet of Things. IEEE Communications Magazine, pp. 168-174.

[45] Elghazel, W., Bahi, J., Guyeux, C., Hakem, M., Medjaher, K. \& Zerhouni, N. 2015. Dependability of wireless sensor networks for industrial prognostics and health management. Computers in Industry, 68, pp. 1-15. 
[46] Gorecky, D., Schmitt, M., Loskyll, M. \& Zühlke, D. 2014. Human-machine-interaction in the Industry 4.0 era. 12th IEEE International Conference on Industrial Informatics, pp. 289-294.

[47] Chen, B., Wan, J., Shu, L., Li, P., Mukherjee, M. \& Yin, B. 2017. Smart factory of Industry 4.0: Key technologies, application case, and challenges. IEEE Access, 6, pp. 6505-6519.

[48] Dallasega, P., Rauch, E. \& Linder, C. 2018. Industry 4.0 as an enabler of proximity for construction supply chains: A systematic literature review. Computers in Industry, 99, pp. 205-225.

[49] Zhang, F., Liu, M., Zhou, Z. \& Shen, W. 2016. An loT-based online monitoring system for continuous steel casting. IEEE Internet of Things Journal, 3(6), pp. 1355-1363.

[50] Du Plessis, J.N., Prinsloo, I.M. \& Groenewald, H.J. 2013. Results from implementing a remote diagnostic and maintenance solution on energy management systems. 2013 International Conference on Industrial and Commercial Use of Energy, pp. 35-40.

[51] Du Plessis, J.N., Pelzer, R. \& Kleingeld, M. 2012. An automated diagnostic system to streamline DSM project maintenance. 2012 International Conference on the Industrial and Commercial Use of Energy, pp. 7-10.

[52] Van Jaarsveld, S., Van Heerden, S.W. \& Van Rensburg, J.F. 2017. Development of a condition monitoring information system for deep level mines. SAIIE28 Proceedings, pp. 3422-1-3422-13.

[53] Goosen, P., Swanepoel, J.A. \& du Plessis, J.N. 2016. The need for a comprehensive energy management information system for industries. South African Journal of Industrial Engineering, 27(3), pp. 1-11.

[54] Goosen, P., Mathews, M.J. \& Vosloo, J.C. 2017. Automated electricity bill analysis in South Africa. South African Journal of Industrial Engineering, 28(3), pp. 66-77.

[55] Peach, P.F.H., Kleingeld, M. \& Bredenkamp, J.I.G. 2017. Optimising deep-level mine refrigeration control for sustainable cost savings. 2017 International Conference on the Industrial and Commercial Use of Energy, p. 8.

[56] Van Jaarsveld, S., Du Plessis, J.N. \& Pelzer, R. 2015. A control system for the efficient operation of bulk air coolers on a mine. 2015 International Conference on the Industrial and Commercial Use of Energy, pp. 133-137.

[57] Vermeulen, J., Cilliers, C. \& Marais, J.H. 2017. Cost-effective compressor control to reduce oversupply of compressed air. 2017 International Conference on the Industrial and Commercial Use of Energy, pp. 17.

[58] Du Plessis, J.N., Pelzer, R. \& Kleingeld, M. 2012. An automated diagnostic system to streamline DSM project maintenance. 2012 International Conference on Industrial and Commercial Use of Energy, pp. 710.

[59] Du Plessis, J.N., Pelzer, R. \& Vosloo, J.C. 2015. Sustaining the performance of diverse energy management systems through reactive maintenance. 2015 International Conference on the Industrial and Commercial Use of Energy, pp. 44-49.

[60] Finogeev, A.G. \& Finogeev, A.A. 2017. Information attacks and security in wireless sensor networks of industrial SCADA systems. Journal of Industrial Information Integration, 5, pp. 6-16.

[61] Prinsloo, J., Mathews, M.J., du Plessis, J.N., \& Vosloo, J.C. 2019. Development of a software-based monitoring and information system for industrial telemetry applications. South African Journal of Industrial Engineering, 30(1), pp. 54-68.

[62] Shabina, S. 2014. Smart helmet using RF and WSN technology for underground mines safety. 2014 International Conference on Intelligent Computing Applications, pp. 305-309.

[63] Hancke, G.P. \& Allen, B. 2006. Ultrawideband as an industrial wireless solution. IEEE Pervasive Computing, 5(4), pp. 78-85.

[64] Behr, C.J., Kumar, A. \& Hancke, G.P. 2016. A smart helmet for air quality and hazardous event detection for the mining industry. Proceedings of the IEEE International Conference on Industrial Technology, pp. 2026-2031.

[65] Trappey, A.J.C., Trappey, C.V., Hareesh Govindarajan, U., Chuang, A.C. \& Sun, J.J. 2017. A review of essential standards and patent landscapes for the Internet of Things: A key enabler for Industry 4.0. Advanced Engineering Informatics, 33, pp. 208-229.

[66] Benešová, A.. \& Tupa, J. 2017. Requirements for education and qualification of people in Industry 4.0. 27th International Conference on Flexible Automation and Intelligent Manufacturing, 11, pp. 2195-2202.

[67] Mohamed, S.M., Hamza, H.S. \& Saroit, I.A. 2017. Coverage in mobile wireless sensor networks (M-WSN): A survey. Computer Communications, 110, pp. 133-150.

[68] Da Xu, L., Member, S., He, W. \& Li, S. 2014. Internet of Things in industries: A survey. IEEE Transactions on Industrial Informatics, 10(4), pp. 2233-2243.

[69] Fraga-Lamas, P., Fernández-Caramés, T.M., Blanco-Novoa, Ó. \& Vilar-Montesinos, M. 2018. A review on industrial augmented reality systems for the Industry 4.0 shipyard. IEEE Access, 6, pp. 13358-13375.

[70] Wang, S., Wan, J., Zhang, D., Li, D. \& Zhang, C. 2016. Towards smart factory for Industry 4.0: A selforganized multi-agent system with big data-based feedback and coordination. Computer Networks, 101, pp. 158-168. 